\title{
Assessing canopy fuel stratum characteristics in crown fire prone fuel types of western North America
}

\author{
Miguel G. Cruz ${ }^{\mathrm{A}}$, Martin E. Alexander ${ }^{\mathrm{B}}$ and Ronald H. Wakimoto ${ }^{\mathrm{C}}$ \\ A Associação para o Desenvolvimento da Aerodinâmica Industrial, Apartado 10131, 3031-601 Coimbra, \\ Portugal; present address: School of Forestry, University of Montana, Missoula, MT 59812, USA. \\ Corresponding author. Telephone: +1 406243 6422; fax: +1 406243 4845; email: mgcruz@selway.umt.edu \\ ${ }^{B}$ Canadian Forest Service, Northern Forestry Centre 5320-122 Street Edmonton, Alberta T6H 3S5, Canada. \\ Telephone: +1 780435 7346; fax: +1 780435 7359; email: malexand@nrcan.gc.ca \\ ${ }^{\mathrm{C}}$ School of Forestry, University of Montana, Missoula, MT 59812, USA. Telephone: +1 406243 6201; \\ fax: +1 406243 4845; email: wakimoto@forestry.umt.edu
}

\begin{abstract}
Application of crown fire behavior models in fire management decision-making have been limited by the difficulty of quantitatively describing fuel complexes, specifically characteristics of the canopy fuel stratum. To estimate canopy fuel stratum characteristics of four broad fuel types found in the western United States and adjacent areas of Canada, namely Douglas-fir, ponderosa pine, mixed conifer, and lodgepole pine forest stands, data from the USDA Forest Service's Forest Inventory and Analysis (FIA) database were analysed and linked with tree-level foliage dry weight equations. Models to predict canopy base height (CBH), canopy fuel load (CFL) and canopy bulk density (CBD) were developed through linear regression analysis and using common stand descriptors (e.g. stand density, basal area, stand height) as explanatory variables. The models developed were fuel type specific and coefficients of determination ranged from 0.90 to 0.95 for CFL, between 0.84 and 0.92 for CBD and from 0.64 to 0.88 for CBH. Although not formally evaluated, the models seem to give a reasonable characterization of the canopy fuel stratum for use in fire management applications.
\end{abstract}

Additional keywords: canopy base height; canopy bulk density; canopy fuel load; crown fire behavior; crown fuel dynamics.

\section{Introduction}

The growing complexity of deterministic fire behavior models implemented in fire management decision support systems requires that descriptions of fuel complex characteristics should be as accurate as possible given the existing resource and knowledge constraints. Until recently in the U.S. fuel complex characterization has been limited to surface fuel beds (e.g. Brown and See 1981; Brown and Bevins 1986) due to the restricted applicability of fire behavior models such as the BEHAVE system (Burgan and Rothermel 1984; Andrews 1986) to this fuel stratum. The development of fire behavior models and systems designed to predict crown fire behavior (Albini 1979, 1996; Van Wagner 1977, 1989; Forestry Canada Fire Danger Group 1992; Call and Albini 1997; Alexander 1998; Finney 1998; Scott and Reinhardt 2001) point out the need to describe the canopy fuel stratum. Based on an analysis of existing fire behavior models and physical reasoning, it is possible to isolate the relevant canopy fuel stratum characteristics that determine crown fire behavior. The canopy structural properties of a stand (e.g. cover, depth, shape, leaf area and leaf distribution) influence understory micrometeorology, and therefore influence certain factors of the fire environment such as subcanopy wind flow (Meyers and Paw U 1987; Amiro 1990) and seasonal and diurnal fuel moisture dynamics (Rothermel et al. 1986).

Since canopy fuels are the main fuel layer supporting crown fire spread, canopy structure largely determines combustion requirements and outputs, and consequently important fire behavior descriptors such as rate of fire spread and fire intensity (Byram 1959). With Finney's (1998) implementation of Van Wagner's (1977) crown fire initiation and spread models into the FARSITE fire growth simulator, information on $\mathrm{CBD}$ and $\mathrm{CBH}$ have become essential for fire management planning (Keane et al. 1998), although no method of easily quantifying these parameters is directly available to fire managers. Such information is needed for other crown fire potential assessment schemes (Alexander 1988; Graham et al. 1999; Keyes and O'Hara 2002).

Fuel complex characteristics commonly accepted as controlling crown fire spread are CFL, canopy fuel bulk density and CBH. When describing aerial fuels the term crown and canopy have often been used interchangeably without formal 
distinction. Within the present study the term 'crown' is applied to describe aerial fuels at the tree level and 'canopy' at the stand level. From the assumption that conifer needles are the main aerial fuel consumed within the flaming front of a crown fire, canopy fuel properties are based on the quantification of live needle foliage. Nevertheless, the authors recognize that, in certain fuel complexes, other fine fuels such as fine live and dead twigs, lichens and bark flakes might significantly contribute to the energy released within the zone of flaming combustion (Call and Albini 1997; Agee et al. 2002). No quantitative description of these fuels was available in the datasets/models used in this study, and consequently they were not included in the analysis. The relevance of CFL in crown fire phenomena is easily understood as it represents the potential energy available to be released from this fuel layer (Byram 1959; Wendel 1960). Canopy fuel bulk density describes the amount of fuel within a unit volume of the canopy and has been used as the main canopy fuel descriptor in empirically based crown fire modeling attempts (Van Wagner 1977; Cruz 1999). This quantity is one of the variables determining the mass flow rate within a crown fire and the main fuel variable discriminating the type of crown fire spread regime (Van Wagner 1977). When considering physically based, radiation driven crown fire models (e.g. Albini and Stocks 1986; Albini 1996; Grishin 1997), CBD is required to estimate the fuel layer optical opacity. Several researchers (Johnson et al. 1998; Stephens 1998; Agee et al. 2000; Fiedler et al. 2001; Fulé et al. 2001) evaluated fire hazard and the effectiveness of fuel treatments on crown fire potential based mostly on the effect of CBD in sustaining active crown fire spread.

$\mathrm{CBH}$ expresses the vertical distance between the surface and live canopy fuel layers. When considering crown fire phenomenology this variable influences: (1) the likelihood of crown fire initiation; and (2) the interaction between the surface and canopy fuel layer, and therefore, the structure of the flame sheet in the subcanopy space after the development of a sustained crown fire. Although there are no published relationships of the decay of the upward heat flux with height above a forest fire, several theoretical and empirical studies (Xanthopoulos 1990; Mercer and Weber 1994; Weber et al. 1995; Alexander 1998) have quantitatively characterized the variation in temperature with height within the convection plume of surface fires and showed the control that this variable has in the onset of crowning.

One of the confounding factors with the estimation of the vertical fuel gap is the definition of the lower limit of the canopy fuel stratum. Several authors (Kilgore and Sando 1975; Van Wagner 1977; Cole and Jensen 1982; Bilgili and Methven 1994; McAlpine and Hobbs 1994; Scott 1998) defined the vertical fuel gap for different fuel types although the definition of the crown base height parameter varied. Some authors defined crown base height as the lower insertion point of live branches in a tree (e.g. Cole and Jensen
1982). Sando and Wick (1972) defined crown base height arbitrarily as the lower vertical $0.3 \mathrm{~m}(1 \mathrm{ft})$ section with a weight greater than $112.4 \mathrm{~kg} \mathrm{ha}^{-1}$ (i.e. $100 \mathrm{lbs} \mathrm{acre}^{-1}$ ), based on the reasoning that there is a minimum amount of fuel required so the fire will support combustion vertically. Ottmar et al. (1998) defined crown base height as 'the height of the lowest continuous branches of the tree canopy' and refined their description of the crown fuel strata, identifying ladder fuels as 'the height of the lowest live or dead branch material that could carry fire into the crown'. The lack of precise standards to define the canopy lower limit also impact the estimation of $\mathrm{CBD}$ due to the difficulty in determining canopy length $(\mathrm{CL})$.

Although there exist a multitude of studies quantifying leaf area and foliage phytomass at the tree level (e.g. Kittredge 1944; Brown 1978; Moeur 1981; Snell and Anholt 1981; Grigal and Kernik 1984; Johnson et al. 1990; Baldwin et al. 1997; Mead 1998; Monserud and Marshal 1999), few studies have been designed to quantify CFL and CBD at the stand level from easily available stand descriptors. Apart from CBD quantification as part of pre-burn fuel sampling in experimental fires (e.g. Van Wagner 1968, 1977; Lawson 1972; Stocks 1987, 1989; Alexander et al. 1991), just some scattered studies (e.g. Alexander 1979; Scott 1998; Scott and Reinhardt 2001) were conducted quantifying canopy fuels to rate the potential for crown fire initiation and spread. The lack of published results on this fuel complex characteristic limits our understanding of the spatial and temporal variability of canopy fuel structure and its implications for the potential of crown fire spread both at the stand and landscape scale.

The objectives of this study are to:

(1) Quantify the natural variability in CFL, CBD and $\mathrm{CBH}$ in some western US fuel types;

(2) Analyse the relationship between these fuel complex descriptors and stand variables collected in forest inventories; and

(3) Develop equations to predict these fuel complex descriptors from commonly available stand data.

To achieve these objectives the study focused on the analysis of stand inventory data from the Forest Inventory and Analysis (FIA) database developed by the USDA Forest Service (Gillespie 1999) and its linkage with tree level foliage biomass regression models.

\section{Methods}

The present study was designed to focus on forest fuel types that are subject to the incidence of crown fires. The definition of the fuel complexes in this category was based on historic fire regime characteristics (Kilgore 1981) and published wildfire case studies (e.g. Anderson 1983; NFPA 1990; Rothermel 1991). The diversity of fuel complexes was further reduced given the available data in the FIA dataset covering 
certain forest types. Four major fuel types were discriminated on the basis of the FIA forest cover type data. The fuel types/cover types were: Douglas-fir (DF), ponderosa pine (PP), lodgepole pine (LP) and mixed conifer (MC). The mixed conifer fuel type integrates several distinct fuel complexes that were merged into a single broad fuel type due the limited number of plots in the database for each type. This fuel type comprised the following forest cover types: white fir and grand fir; Engelmann spruce; Engelmann spruce-subalpine fir; western red cedar; mountain hemlock-subalpine fir; western hemlock; and larch-Douglas-fir.

\section{Stand data source}

The stand and tree data source selected for this study was the USDA Forest Service's Forest Inventory and Analysis (FIA) program (Gillespie 1999). The FIA program maintains a network of permanent plots throughout the United States aimed at providing consistent information on the status of forest resources nationwide. The representativeness of the original FIA data with one sample location per approximately 2430 ha ( $\sim 6000$ acres) on a national scale gives robustness to the aim of the present study in assessing the distribution of canopy fuels characteristics in the western U.S. fuel types that are prone to crowning. The FIA plot data analysed was a sample of the original FIA ground plots. Plot selection was limited to the four broad conifer fuel types selected. Within the FIA methodology the predominant forest type of the area where the plot is located defines the cover type. For the western States, data availability was restricted to Arizona, Colorado, Idaho, Montana and New Mexico. Data from each state was sorted by cover type (comprising the cover types discriminated above) and basal area, and a systematic sample of 100 plots by state was applied. Further reduction of the dataset for analysis was conducted to eliminate plots that had a substantial component of deciduous trees; plots with a proportion of deciduous basal area higher than $15 \%$ were removed. This was justified on the basis of the generally low flammability of live foliage of North American broadleaf deciduous species found in western North America (Van Wagner 1977). The total number of plots used in the analysis was 476 .

Generally a FIA ground plot covers an area of $\sim 0.405$ ha (1 acre) but larger sample areas were occasionally used involving various fixed and variable radius (prism) sample points. A diverse set of measurements and estimates are made for each sample tree (Woudenberg and Farrenkopf 1995). These tree attribute data were the basis of the present study as they allow the reconstruction of stand structure at the tree level and subsequent estimation of $\mathrm{CBH}$ and the application of foliage weight equations to individual trees for the estimation of CFL and CBD. Figure 1 outlines the process

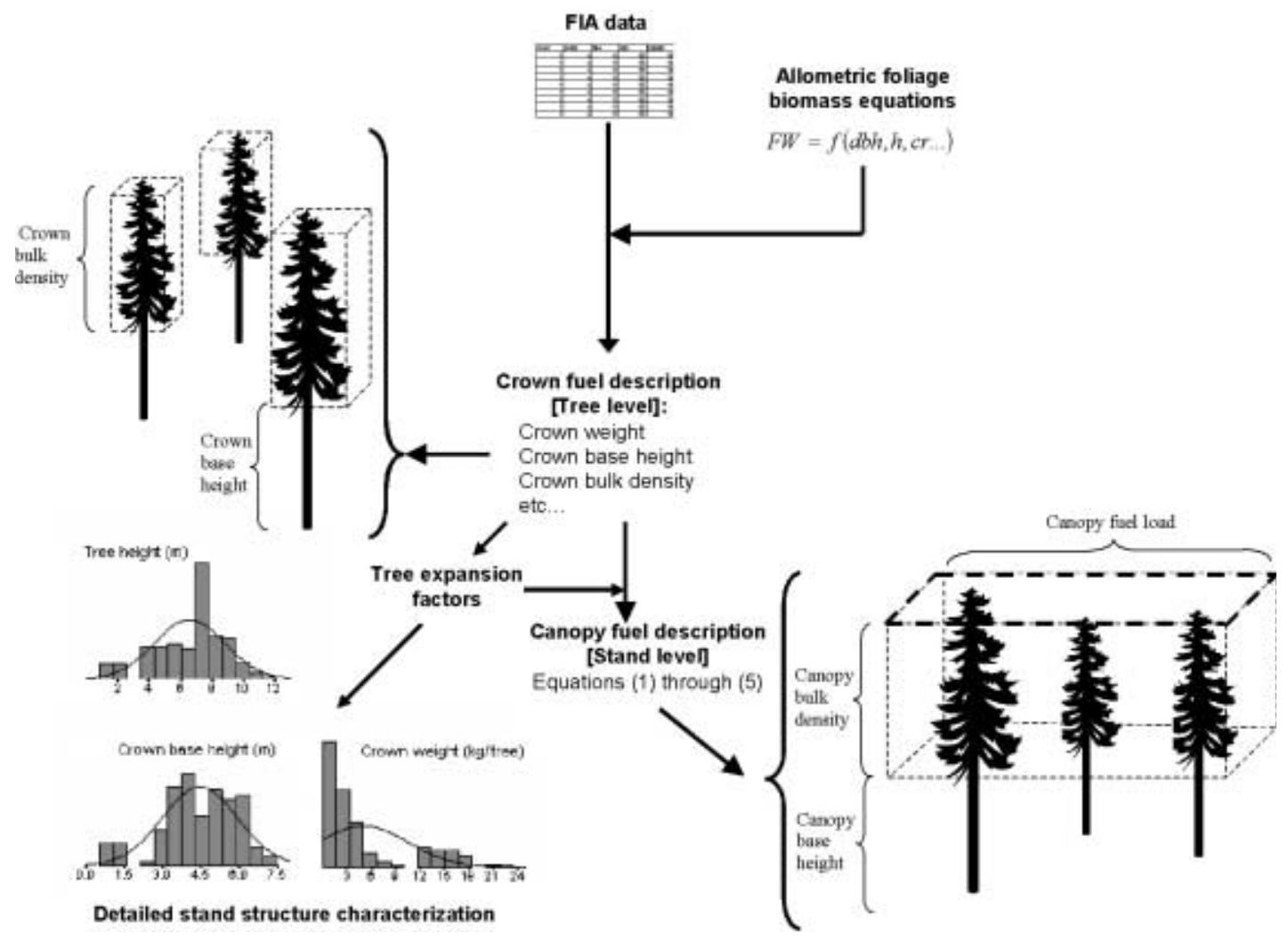

Fig. 1. Diagram illustrating data linkages used to estimate detailed canopy fuel characteristics from initial FIA plot data and published foliage biomass equations. 
used to derive the canopy fuel characteristics for a particular stand. From the basic tree attribute data, tree diameter at breast height, tree height, crown ratio, crown class (crown position), and tree expansion factor were used in this study. The tree expansion factor expresses the number of trees per unit area that each sampled tree represents in the inventory (Woudenberg and Farrenkopf 1995).

\section{Selection of foliage weight equations}

The quantification of crown biomass is a valuable piece of information for several areas of study such as fire management, whole tree utilization, forest ecology, and nutrient cycling. Many authors have related crown biomass or foliage biomass with tree dendrometric characteristics through dimensional analysis. There are a large number of studies (e.g. Kittredge 1944; Weetman and Harland 1964; Kiil 1967; Stiell 1969; Baskerville 1972; Brown 1978; Green and Grigal 1978; Loomis and Roussopoulos 1978; Rencz and Auclair 1980; Stocks 1980; Moeur 1981; Snell and Anholt 1981; Agee 1983; Grigal and Kernik 1984; Johnson et al.
1990) that estimate crown foliage and branch biomass at the tree level using allometric relations that link those quantities with tree diameter and height. Because of this, criteria needed to be defined in order to select the most appropriate equations to be used in the present study. For a relatively comprehensive listing of studies in North America see Ter-Mikaelian and Korzukhin (1997).

The criteria to restrict the number of studies considered, were:

(1) To give preference to studies developing equations for several species in order to avoid variability introduced by different sampling methods;

(2) The use of equations that discriminate foliage biomass, since some of the studies yield crown weight lumping together foliage and fine branch weight; and

(3) To give preference to equations valid for the regions under study in order to avoid regional variability (Green and Grigal 1978; Stocks 1980; Grigal and Kernik 1984).

A list of the species considered and respective equation sources is given in Table 1 .

Table 1. Tree species and foliage weight equation sources for the estimation of stand level CBD

Abbreviations: BP, bristlecone pine (Pinus aristata); BS, blue spruce (Picea pungens); CF, corkbark fir (Abies lasiocarpa var. arizonica); CP, cottonwood and poplar (Populus spp.); LP, limber pine (Pinus flexilis); MH, mountain hemlock (Tsuga mertensiana); SWP, Southwestern white pine (Pinus strobiformis); TP, two-needle pinyon (Pinus edulis); WPB, western paper birch (Betula papyrifera); WF, white fir (Abies concolor)

\begin{tabular}{|c|c|c|c|c|c|}
\hline Tree species & Data origin & $n$ & $\begin{array}{c}\text { Basal area } \\
\text { range }\left(\mathrm{m}^{2} \mathrm{ha}^{-1}\right)\end{array}$ & Source & Surrogate for \\
\hline $\begin{array}{l}\text { Black spruce } \\
\quad \text { Picea mariana }\end{array}$ & Ontario, Canada & 62 & $10-29$ & Stocks (1980) & - \\
\hline $\begin{array}{l}\text { Douglas-fir } \\
\quad \text { Pseudotsuga menziesii }\end{array}$ & Montana/Idaho & 41 & $0.5-55$ & Brown (1978) & - \\
\hline $\begin{array}{l}\text { Lodgepole pine } \\
\text { Pinus contorta }\end{array}$ & Montana/Idaho & 15 & - & Brown (1978) & - \\
\hline $\begin{array}{l}\text { Ponderosa pine } \\
\text { Pinus ponderosa }\end{array}$ & Montana/Idaho & 45 & $0.2-62$ & Brown (1978) & - \\
\hline $\begin{array}{l}\text { Subalpine fir } \\
\text { Abies lasiocarpa }\end{array}$ & Montana/Idaho & 40 & $0.2-75$ & Brown (1978) & - \\
\hline $\begin{array}{l}\text { Western hemlock } \\
\text { Tsuga heterophylla }\end{array}$ & Montana/Idaho & 15 & - & Brown (1978) & MH \\
\hline $\begin{array}{l}\text { Western larch } \\
\quad \text { Larix occidentalis }\end{array}$ & Montana/Idaho & 16 & $0.2-60$ & Brown (1978) & - \\
\hline $\begin{array}{l}\text { Western redcedar } \\
\text { Thuja plicata }\end{array}$ & Montana/Idaho & 34 & $10-77$ & Brown (1978) & \\
\hline $\begin{array}{l}\text { Western white pine } \\
\text { Pinus monticola }\end{array}$ & Montana/Idaho & 44 & $0.2-32$ & Brown (1978) & SWP \\
\hline $\begin{array}{l}\text { Whitebark pine } \\
\text { Pinus albicaulis }\end{array}$ & Montana/Idaho & 10 & $0.2-42$ & Brown (1978) & BP, TP, LP \\
\hline $\begin{array}{l}\text { Trembling aspen } \\
\quad \text { Populus tremuloides }\end{array}$ & Minnesota & 15 & - & $\begin{array}{l}\text { Loomis and } \\
\text { Roussopoulos (1978) }\end{array}$ & WPB, CP \\
\hline $\begin{array}{l}\text { Engelmann spruce } \\
\text { Picea engelmannii }\end{array}$ & Montana/Idaho & 29 & $0.2-42$ & Brown (1978) & BS \\
\hline $\begin{array}{l}\text { Grand fir } \\
\quad \text { Abies grandis }\end{array}$ & Montana/Idaho & 35 & $9-68$ & Brown (1978) & WF, CF \\
\hline $\begin{array}{l}\text { White spruce } \\
\text { Picea glauca }\end{array}$ & Ontario, Canada & 43 & - & Stiell (1969) & - \\
\hline
\end{tabular}


This list is broader than the list of species considered in the fuel types because it includes all the tree species encountered in the plots. The main source of foliage weight equations (11 of 14 models) used in this study was Brown (1978), which covers a large number of species over a wide region. This was done to minimize variability arising from differences in sampling methodologies. The equations inputs and forms varied with the species and source. For some species found in the FIA plot data, no published foliage equations were found (Table 1). To estimate foliage weight of these species, surrogate species were used. The decision as to which species should be used as a surrogate (Table 1) was based on similarities in tree crown structure (cf. Albini 1979). By linking the basic tree attribute data with the allometric equations describing foliage biomass at individual tree level, we were able to estimate crown foliage biomass.

\section{Estimation of canopy fuel structure}

After the estimation of crown foliage biomass, CFL in $\mathrm{kg} \mathrm{m}^{-2}$ was estimated as:

$$
C F L=\frac{\sum_{i=1}^{n}\left(f w_{i} \times T E F_{i}\right)}{10000}
$$

where $f w_{i}$ is foliage weight $(\mathrm{kg})$ on a per tree basis for the $i$ th tree, and $T E F_{i}$ is the tree expansion factor corrected to a per hectare basis for the $i$ th tree.

CBD expressed in $\mathrm{kg} \mathrm{m}^{-3}$ was estimated through:

$$
C B D=\frac{C F L}{C L},
$$

where CL is the average length of the canopy fuel stratum (m). CL was estimated as:

$$
C L=\frac{\sum_{i=1}^{n}\left(c l_{i} \times T E F_{i}\right)}{\sum_{i=1}^{n} T E F_{i}},
$$

where $c l_{i}$ is the crown length (m) of the $i$ th sample tree in the plot.

$\mathrm{CBH}$ was estimated as:

$$
C B H=\frac{\sum_{i=1}^{n}\left(c b h_{i} \times T E F_{i}\right)}{\sum_{i=1}^{n} T E F_{i}},
$$

where $C B H$ is the stand mean $\mathrm{CBH}(\mathrm{m})$, and $c b h_{i}$ is the crown base height $(\mathrm{m})$ of the $i$ th sample tree in the plot, estimated from

$$
c b h_{i}=h_{i}-\left(h_{i} \times c r_{i}\right),
$$

where $h_{i}$ is the tree height (m) of the $i$ th sample tree in the plot; and $c r_{i}$ is the crown ratio of the $i$ th sample tree in the plot.* $^{*}$

\footnotetext{
* Crown ratio is expressed as the percentage of the compacted portion of the tree bole supporting live, healthy foliage when compared to total height (Woudenberg and Farrenkopf 1995). For details of the various methods and definitions used by FIA see http://fia.fs.fed.us/library.htm.
}

\section{Data analysis and results}

\section{General statistics}

After calculating CFL, CBD and $\mathrm{CBH}$, the plot data were screened for type (through scatter plot analysis) and significance (through Pearson correlation coefficient and Kendall's $\tau$ when appropriate) of relationships between the three fuel complex quantities and common stand structure descriptors (stand density, mean stand height, basal area, site index, stand age, CL, crown ratio). SPSS 8.0 (Norušis 1997) software was used for all statistical analysis throughout this study. Table 2 presents general statistics for the various variables under analysis.

Analysis of Pearson's correlation coefficient matrices (not shown) showed that both CFL and CBD were significantly correlated (at the 0.01 level) with stand density and basal area for the four broad fuel types. This would be expected since the two later variables are measures of stand occupancy. These latter two variables were also significantly correlated (at the 0.01 level) for the fuel types considered. Stand mean height was significantly negatively correlated with CBD for the Douglas-fir, ponderosa pine and mixed conifer fuel types. $\mathrm{CBH}$ was significantly correlated (at the 0.01 level) with stand height and basal area for all fuel types under scrutiny. Stand density did show a moderate linear relationship with $\mathrm{CBH}$ although it was not significant (at the 0.05 level) for all fuel types. Neither site index and stand age (based on dominant and co-dominant trees) were significantly correlated with any of the canopy fuel characteristics under analysis. Scatter plot analysis showed linear relationships between CFL-stand density, CFL-basal area, CBD-stand density and CBD-basal area for all fuel types under analysis, nevertheless revealed heteroscedasticity. In other words, there existed an increase in the variance of CBD with increasing stand density and basal area. Scatter plot analysis of $\mathrm{CBH}$ versus the explanatory variables describing stand structure did not raise any statistical limitations for further modeling of $\mathrm{CBH}$ through linear regression analysis.

\section{CFL distribution}

Insight into the CFL distribution for the various fuel types under scrutiny comes from the analysis of the general statistics in Table 2. Of the four broad fuel types, mixed conifer had the highest mean CFL, $1.4 \mathrm{~kg} \mathrm{~m}^{-2}$, followed by lodgepole pine $\left(1.0 \mathrm{~kg} \mathrm{~m}^{-2}\right)$, Douglas-fir $\left(0.83 \mathrm{~kg} \mathrm{~m}^{-3}\right)$, and ponderosa pine $\left(0.61 \mathrm{~kg} \mathrm{~m}^{-2}\right)$. Scheffe's multiple comparison method was used to compare variation between the CFL by fuel type. CFL for lodgepole pine and Douglas-fir broad fuel types were not significantly different at a $0.05 \alpha$ level. All distributions were asymmetric, positively skewed (Fig. 2). The computed skewness for the four fuel types (standard deviation in parentheses) was: 0.85 (0.21) for Douglas-fir; 1.1 $(0.18)$ for ponderosa pine; $0.4(0.24)$ for mixed conifer; and 1.3 (0.33) for lodgepole pine. All skewnesses, but for mixed 
Table 2. General statistics for computed canopy fuel quantities and FIA plot data Min, minimum value; Max, maximum value; s.d., standard deviation

\begin{tabular}{lccccc}
\hline $\begin{array}{l}\text { Fuel type (sample } \\
\text { size) and statistics }\end{array}$ & $\begin{array}{c}\mathrm{CFL} \\
\left(\mathrm{kg} \mathrm{m}^{-2}\right)\end{array}$ & $\begin{array}{c}\mathrm{CBH} \\
(\mathrm{m})\end{array}$ & $\begin{array}{c}\mathrm{CBD} \\
\left(\mathrm{kg} \mathrm{m}^{-3}\right)\end{array}$ & $\begin{array}{c}\text { Basal area } \\
\left(\mathrm{m}^{2} \mathrm{ha}^{-1}\right)\end{array}$ & $\begin{array}{c}\text { Trees per ha } \\
\left(n \mathrm{ha}^{-1}\right)\end{array}$ \\
\hline $\begin{array}{l}\text { Douglas-Fir }(n=132) \\
\text { Min/Max }\end{array}$ & $0.2 / 2.52$ & $0.3 / 18$ & $0.1 / 0.99$ & $0.4 / 60.8$ & $16 / 4731$ \\
Mean (s.d.) & $0.83(0.52)$ & $5.7(3.6)$ & $0.18(0.16)$ & $23.8(13.5)$ & $788(735.6)$ \\
Ponderosa pine $(n=190)$ & & & & \\
Min/Max & $0.04 / 1.96$ & $0.3 / 12.6$ & $0.01 / 0.76$ & $1.36 / 60.8$ & $6 / 9735$ \\
Mean (s.d.) & $0.61(0.37)$ & $4.5(2.2)$ & $0.18(0.15)$ & $16(9.5)$ & $730(1023)$ \\
Mixed Conifer $(n=101)$ & & & & & \\
Min/Max & $0.02 / 3.62$ & $1.3 / 23.8$ & $0.01 / 1.11$ & $1.26 / 80.4$ & $27 / 5629$ \\
Mean (s.d.) & $1.40(0.77)$ & $5.7(3.8)$ & $0.32(0.23)$ & $32(17.5)$ & $1396(1092)$ \\
Lodgepole pine $(n=52)$ & & & & & \\
Min/Max & $0.24 / 2.90$ & $0.7 / 13.4$ & $0.04 / 0.96$ & $6.8 / 80.6$ & $240 / 8202$ \\
Mean (s.d.) & $1.0(0.57)$ & $6.1(3.2)$ & $0.28(0.2)$ & $29.6(15.4)$ & $1955(1513)$ \\
\hline
\end{tabular}
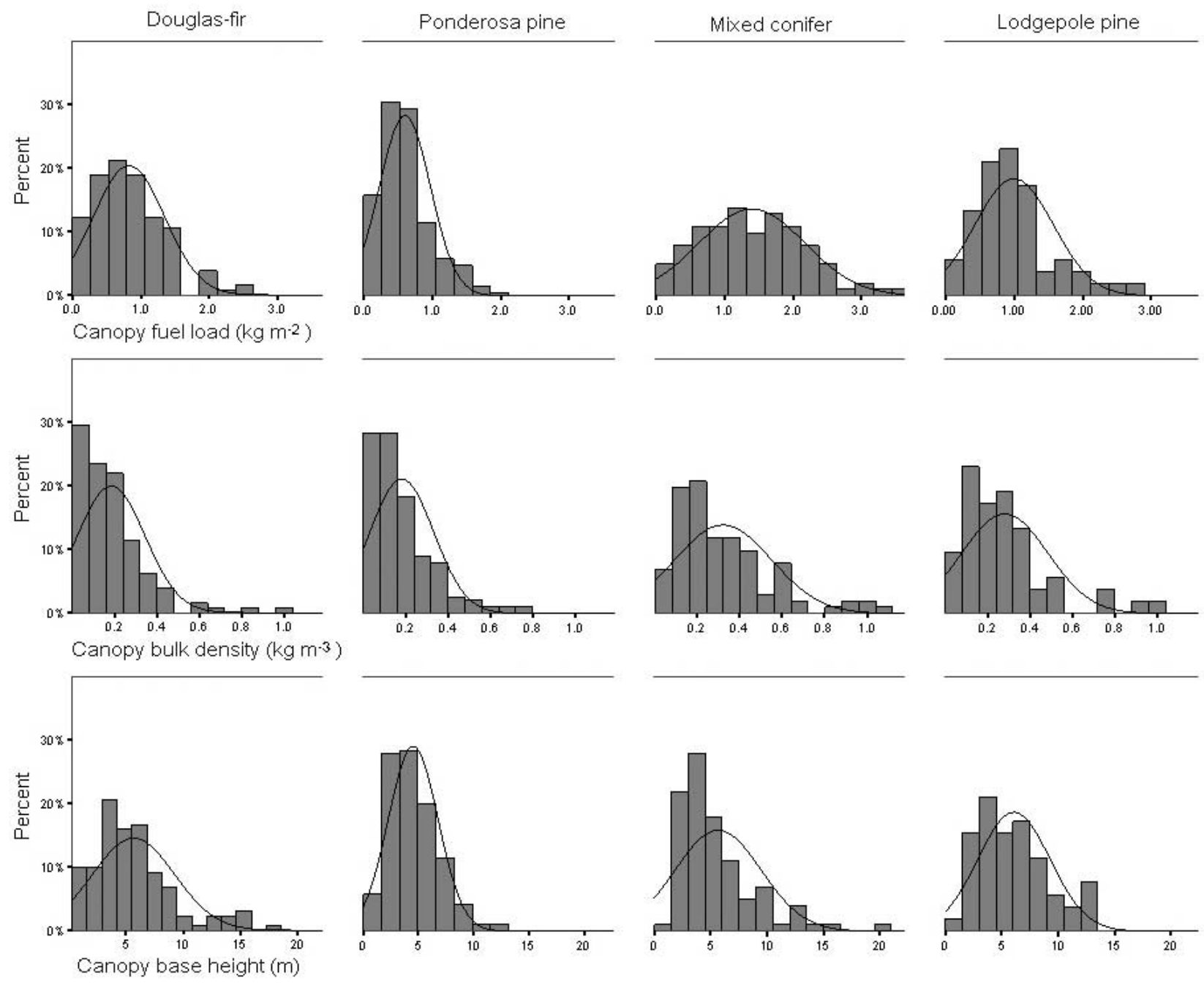

Fig. 2. Distribution of computed CFL (top), CBD (center) and CBH (bottom) for the four broad fuel types under analysis. 
conifer, were larger than two standard errors of skewness, revealing strong skewnesses.

\section{CBD distribution}

Douglas-fir and ponderosa pine had very similar CBD distributions, with a mean and standard deviation of $0.18 \mathrm{~kg} \mathrm{~m}^{-3}$, 0.16 and $0.18 \mathrm{~kg} \mathrm{~m}^{-3}, 0.15$ respectively. Higher bulk densities characterize lodgepole pine and mixed conifer fuel types. As expected by the multi-layered canopy structure that characterizes most of the forest types that contribute to the mixed conifer fuel type, this fuel type showed the highest mean CBD $\left(0.32 \mathrm{~kg} \mathrm{~m}^{-3}\right)$ and also a flatter distribution (Fig. 2). The lodgepole pine fuel type, a fuel type typically associated with high intensity crown fire regimes (Kilgore 1981), also exhibited high estimated CBD values, with a slightly lower mean $\left(0.28 \mathrm{~kg} \mathrm{~m}^{-3}\right)$ and standard deviation (0.2). All distributions were asymmetric, positively skewed (Fig. 2). The computed skewness for the four fuel types (standard deviation in parentheses) were: $2.0(0.21)$ for Douglas fir; 1.6 $(0.17)$ for ponderosa pine; $1.3(0.24)$ for mixed conifer; and 1.7 (0.33) for lodgepole pine. Scheffe's multiple comparison method was used to compare variation between the CBD by fuel type. Two homogeneous groups could be differentiated based on this test. The CBD values across stands of Douglasfir and ponderosa pine fuel types, and mixed conifer and lodgepole pine fuel types were not significantly different (at an $\alpha$ level of 0.05 ).

\section{CBH distribution}

$\mathrm{CBH}$ did not show as much variability between fuel types as did the other canopy fuel variables (Table 2). Scheffe's multiple comparison method was also used to compare variation between fuel type CBH. Douglas-fir, mixed conifer and lodgepole pine fuel types did not show significant differences between them (at an $\alpha$ level of 0.05). CBH for the ponderosa pine fuel type was significantly lower than the other three fuel types, perhaps reflecting the low density, open structure that characterizes this fuel complex. All $\mathrm{CBH}$ distributions also revealed strong skewness (Fig. 2), although not so marked as for CBD. The computed skewnesses were: $1.7(0.21)$ for Douglas-fir; $0.8(0.8)$ for ponderosa pine; $2.1(0.24)$ for mixed conifer; and 0.7 (0.33) for lodgepole pine.

\section{Regression analysis}

Within the present study it was reasoned that, given the previous statistical analysis, linear regression analysis was suitable to develop models for predicting $\mathrm{CBD}$ and $\mathrm{CBH}$ from commonly measured forest stand descriptors. Model form was:

$$
y_{i}=\beta_{0}+\beta_{1} x_{1}+\beta_{2} x_{2}+\cdots+\beta_{i} x_{i}+\varepsilon_{i},
$$

where $y_{i}$ is the characteristic of interest, $\beta_{i}$ are the coefficients estimated from the data through regression analysis, $x_{i}$ are the independent variables, and $\varepsilon_{i}$ is the random error on $y_{i}$.

Given the heteroscedasticity present in the relationship between CFL/CBD and basal area and stand density and the consequent violation of required assumptions of linear regression analysis, these two variables were modeled using logarithmic transformation (Draper and Smith 1981), the resulting model being:

$$
\ln y_{i}=\beta_{0}+\beta_{1} \ln x_{1}+\beta_{2} \ln x_{2}+\cdots+\beta_{i} \ln x_{i}+\varepsilon_{i} \text {. }
$$

Further considerations taken into account in model building were the significance of the parameter estimates (at $\alpha=0.05)$, biological validity of the relationship, and multicollinearity considerations.

\section{CFL modeling}

Given the individual tree and stand structural differences among the fuel types considered in this study, the models to be developed were fuel type specific. From the linear relationships and non-homogeneity of variance found in CFL and the explanatory variables under analysis, linear regression analysis of $\log$ transformed data was used to model CFL as a function of stand density and basal area. The equations explained between 90 and $95 \%$ of the variability in the datasets (Table 3). All the coefficients were significant at the $0.01 \alpha$ level.

The minor effect that basal area has in the models, verified by the basal area coefficients, might be the consequence of the non-independence of basal area and stand density which are both descriptors of site occupancy. Within the dataset, basal area and stand density were significantly linearly correlated for all fuel types. This might lead to multicollinearity and

Table 3. CFL models coefficients and basic statistics for the four broad fuel types

$\mathrm{CFL}$ in $\mathrm{kg} \mathrm{m}^{-3}$; stand density (TPH) in trees per hectare; basal area $(\mathrm{G}) \mathrm{in} \mathrm{m}^{2} \mathrm{ha}^{-1}$. Standard deviation in

\begin{tabular}{|c|c|c|c|c|c|c|}
\hline \multirow[t]{2}{*}{ Fuel type } & \multicolumn{3}{|c|}{ Coefficients in lnCFL $=\beta_{0}+\beta_{1 \mathrm{~L}} n \mathrm{G}+\beta_{2 \mathrm{~L}} n \mathrm{TPH}$} & \multirow[t]{2}{*}{$n$} & \multirow[t]{2}{*}{ Adj. $R^{2}$} & \multirow[t]{2}{*}{ SEE } \\
\hline & $\beta_{0}$ & $\beta_{1}$ & $\beta_{2}$ & & & \\
\hline Douglas-fir & $-3.959(0.095)$ & $0.826(0.026)$ & $0.175(0.019)$ & 132 & 0.95 & 0.192 \\
\hline Ponderosa pine & $-3.592(0.07)$ & $0.864(0.028)$ & $0.110(0.015)$ & 190 & 0.92 & 0.188 \\
\hline Mixed conifer & $-4.824(0.217)$ & $0.804(0.047)$ & $0.333(0.039)$ & 101 & 0.90 & 0.282 \\
\hline Lodgepole pine & $-4.066(0.215)$ & $0.910(0.046)$ & $0.130(0.038)$ & 52 & 0.94 & 0.144 \\
\hline
\end{tabular}
parentheses. All coefficients significant at the $0.01 \alpha$ level 
Table 4. CBD models coefficients and basic statistics for the four broad fuel types

CBD in $\mathrm{kg} \mathrm{m}^{-3}$; stand density (TPH) in trees per hectare; basal area $(\mathrm{G}) \mathrm{in} \mathrm{m}^{2} \mathrm{ha}^{-1}$. Standard deviation in parentheses. All coefficients significant at the $0.01 \alpha$ level

\begin{tabular}{lcccccc}
\hline Fuel type & \multicolumn{2}{c}{ Coefficients in $\operatorname{lnCBD}=\beta_{0}+\beta_{1 \mathrm{~L}} n \mathrm{G}+\beta_{2 \mathrm{~L}} n \mathrm{TPH}$} & & \multirow{2}{c}{ Adj. $R^{2}$} & SEE \\
\cline { 2 - 4 } & \multicolumn{1}{c}{$\beta_{0}$} & $\beta_{1}$ & \multicolumn{1}{c}{$\beta_{2}$} & & & \\
\hline Douglas-fir & $-7.38(0.141)$ & $0.479(0.039)$ & $0.625(0.028)$ & 132 & 0.92 & 0.286 \\
Ponderosa pine & $-6.649(0.115)$ & $0.435(0.047)$ & $0.579(0.025)$ & 190 & 0.90 & 0.309 \\
Mixed conifer & $-8.445(0.252)$ & $0.319(0.054)$ & $0.859(0.045)$ & 101 & 0.89 & 0.327 \\
Lodgepole pine & $-7.852(0.422)$ & $0.349(0.091)$ & $0.711(0.074)$ & 52 & 0.84 & 0.282 \\
\hline
\end{tabular}

Table 5. CBH models coefficients and basic statistics for the four broad fuel types $\mathrm{CBH}$ in $\mathrm{m}$; stand height (SH) in $\mathrm{m}$; basal area $(\mathrm{G})$ in $\mathrm{m}^{2} \mathrm{ha}^{-1}$. Standard deviation in parentheses. All coefficients significant at the $0.01 \alpha$ level

\begin{tabular}{|c|c|c|c|c|c|c|}
\hline \multirow[t]{2}{*}{ Fuel type } & \multicolumn{3}{|c|}{ Coefficients in $\mathrm{CBH}=\beta_{0}+\beta_{1} \mathrm{SH}+\beta_{2} \mathrm{G}$} & \multirow[t]{2}{*}{$n$} & \multirow[t]{2}{*}{ Adj. $R^{2}$} & \multirow[t]{2}{*}{ SEE } \\
\hline & $\beta_{0}$ & $\beta_{1}$ & $\beta_{2}$ & & & \\
\hline Douglas-fir & $-1.771(0.362)$ & $0.554(0.024)$ & $0.045(0.01)$ & 132 & 0.82 & 1.525 \\
\hline Ponderosa pine & $0.134(0.28)$ & $0.393(0.022)$ & $0.049(0.01)$ & 190 & 0.64 & 1.350 \\
\hline Mixed conifer & $-1.463(0.352)$ & $0.578(0.026)$ & $0.026(0.01)$ & 101 & 0.86 & 1.429 \\
\hline Lodgepole pine & $-1.475(0.425)$ & $0.613(0.040)$ & $0.043(0.01)$ & 52 & 0.88 & 1.106 \\
\hline
\end{tabular}

its consequent impact on regression coefficients estimation, such as, sensibility of coefficients to small changes in the data, high standard errors, wrong sign and unreasonable magnitude (Kozak 1997). Variance inflation factors (VIF) were computed for the various models, ranging from 1.6 to 1.8 , indicating that multicollinearity was marginal in these models. The expansion of the equations in Table 3 by the introduction of interaction terms was attempted. Nevertheless, the interaction coefficients were not significant and its use resulted in a large increase of VIF.

\section{CBD modeling}

As for CFL, CBD was modeled after logarithmic transformation. Explanatory variables used were stand density and basal area (Table 4). Although stand mean height was significantly correlated with CBD for the Douglas-fir, ponderosa pine and mixed conifer fuel types, its use as an explanatory variable was not pursued since it would increase the data requirements for predicting $\mathrm{CBD}$ and did not significantly reduce the unexplained variability. All the coefficients were significant at the $0.01 \alpha$ level. The four equations yield adjusted coefficients of determination between 0.84 and 0.92 , revealing an acceptable fit of the model to the data. Standard errors of estimate ranged from 0.282 for lodgepole pine to 0.327 to mixed conifer. VIF were computed for the various models, ranging from 1.6 to 1.8. As for the CFL equations, adding interaction terms did not prove advantageous.

The results shown in Table 4 emphasize the model's structure, with a strong dependence of CBD on tree density, and a minor effect of basal area. In low bulk density situations the models produce higher relative differences between them. For stands characterized by high densities and basal areas all the models, except for ponderosa pine, yield similar values. The equation developed for lodgepole pine yields lower CBD, given similar stand characteristics, when compared with the other fuel complexes. The results from the multiple comparisons tests suggests that the data from the four broad fuel types could be pooled into two groups (one for Douglasfir and ponderosa pine and the other for mixed conifer and lodgepole pine) and two equations would be sufficient to model CBD. Evidence from the models behavior for low CBD (where crown fire behavior models are most sensitive to changes in canopy fuel structure) suggests that the merging of the datasets would result in larger errors and increase uncertainty on fire behavior predictions in such type of stands. This justified the pursuit of a four model solution.

\section{CBH modeling}

The same reasoning presented for $\mathrm{CBD}$ concerning fuel type specific equations applies to $\mathrm{CBH}$ modeling. Linear regression analysis was applied in an attempt to explain the variability of this dependent variable. Table 5 gives the coefficients for the four equations developed using the equation (6) model form as well as the basic statistics. All the coefficients were significant at the $0.01 \alpha$ level. The equations explained between 64 and $88 \%$ of the variability in the datasets, with the standard errors of estimate ranging from 1.106 for lodgepole pine and 1.525 for Douglas-fir fuel type. As expected, by biological reasoning, stand height had the most effect on $\mathrm{CBH}$. The $\beta_{1}$ coefficient expresses the increase in $\mathrm{CBH}$ 
with the increase in stand height. Within a stand, environment (mainly light) and physiological constrains limit CL. As such, the base of the canopy is expected to move vertically along the stem with the increase in stand height. Small stand height coefficients are associated with larger crown ratios. Basal area showed a small effect in determining $\mathrm{CBH}$ but its inclusion in the models was justified by the need to include a site occupancy descriptor, and its expected effect on light penetration into the lower layers of the canopy. Light environment, both light quantity and quality, are likely to decrease/deteriorate in the lower levels of the canopy with an increase in site occupancy. Inclusion of other variables well correlated with $\mathrm{CBH}$ (e.g. stand density) did not improve model fit significantly as those variables were already highly correlated with stand height and basal area, respectively.

\section{Conclusions}

The objective of this study was to quantify the variability and develop tools to assess the canopy fuel stratum descriptors commonly used in predicting crown fire behavior. No emphasis was placed on conducting a thorough analysis of these variables by discussing theoretical considerations such as their dependency on site characteristics, stand structure, species crown architecture and physiological adaptations to competition. Currently the more accurate way to estimate CFL and CBD is to apply foliage biomass equations to an actual stand structure (Alexander 1979, 1998; Agee 1996; Scott 1998). The present study concentrated in four broad fuel types of western North America. A subset of an extensive stand database distributed over the states of Montana, Idaho, Colorado, Arizona and New Mexico was linked with foliage biomass equations in order to estimate the variability in $\mathrm{CFL}, \mathrm{CBD}$ and $\mathrm{CBH}$, and develop regression models for its estimation from common stand inventory data. The foliage equations were applied without regard to the effect of stocking, age and site quality on the foliage weight equation. It is expected that for forest stands with high densities and/or basal areas, the estimated CFL and CBD values might show an over-prediction bias, as the dimensional relationships for which the allometric equations were built are dependent on age (Baskerville 1983), density and site quality (Long and Smith 1988).

Although Brown (1978) in his destructive sampling of tree crowns sampled trees from a wider range of stand densities than the stands summarized in Table 2, over-prediction of CFL and CBD should occur in overstocked stands. This arises from the size-stand basal area relationship encountered in the trees used to develop the allometric foliage biomass equations, and how representative those relationships are for overstocked stands. Within the Brown (1978) dataset the small and medium d.b.h. trees were associated with low basal areas. The sampling concentrated on dominant and codominant trees, with some sampling of intermediate trees. The resulting allometric relationships are expected to differ from the relations existent in trees growing in overstocked stands, where restricted light conditions limit the quantity of live foliage per tree.

It is difficult to determine at what level of stand density the estimates began to over-predict CFL and CBD. One of the limitations of the current modeling approach was that the models built attempt to describe only the canopy live fuels, not addressing ladder fuels that effectively reduce the vertical gap between the surface and canopy fuel layers. The characteristics of the FIA dataset constrained the modeling approach followed in this study regarding the vertical stratification of the fuel complex. Nevertheless, this limitation does not restrict the applicability of the results obtained as the nature and characteristics of ladder fuel dynamics and their effect on fire behavior are still not well understood (Muraro 1971; Lawson 1972; Alexander 1998). Analysis of the Scheffe's multiple comparison results and regression coefficients reveal that some of the broad fuel types could be put together and a smaller number of equations developed. This approach would however result in a reduction of the discriminating power of the models, namely for low CFL and CBD ranges where crown fire behavior models are most sensitive to changes in canopy fuel structure (Van Wagner 1977; Cruz 1999).

The fuel type specific models developed in this study provide a reasonable approximation of a forest stand canopy fuel structure to support fire management decision-making. Although simple, the various fuel type specific models developed seem to capture well the variability in the dataset. Two aspects that were not included in the work and that would complement the research carried out were: (1) the evaluation of the various regression models built; and (2) the development of a canopy fuel characteristics photo guide to accompany the quantitative canopy fuel information gathered from the application of the models. Model development should be accompanied by model evaluation so better understanding of model behavior and limitations is gained. Such task was not pursued in the present study. The main sources of possible bias/error in the regression models developed are the foliage biomass models/data used in the derivation of the tree level data and the procedure (i.e. equations 1, 2, 3, and 5) used to infer stand level quantities. The evaluation of the CFL and CBD models with the results obtained in studies done by others, such as Alexander (1979, 1998), Scott (1998) and Ottmar et al. (1998), would be inconclusive as they support their results in the same basic approach (i.e. apply foliage biomass equations to a particular stand structure to deduce canopy fuel characteristics). Disparity in the results would arise primarily from the source of the foliage biomass equations. Direct evaluation of the CFL and CBD models against independent data would require the sampling of a large number of forest stands and the destructive sampling of a relatively large number of trees (Cruz and Viegas 1998), an Herculean task outside the scope of the present study. 
The understanding of fire dynamics at the landscape level can greatly benefit from the use of deterministic models expressing various fire behavior descriptors influencing fire effects at various temporal and spatial scales. One of the main limiting aspects in analysing results from fire spread simulations at large spatial scales has been the uncertainty derived from our inability to describe the distribution of canopy fuels at such a scale and the resulting crown fire behavior. The models developed in the present study allow assembling of critical data layers describing fuel complex information required to predict crown fire behavior. Such information can be used to support decision making in a large array of fire management problems (Anderson 1974a, 1974b), ranging from prescribed fire planning, analysis of fuel treatment effectiveness at the landscape level or prediction of crown fire behavior to support wildfire suppression.

\section{Acknowledgements}

The authors thank the USDA Forest Service Forest Inventory and Analysis Program for making available its database for the present study. Thanks to Dr Kelsey Milner of the University of Montana for early guidance and continuous advice. This research was completed while Miguel Cruz was a graduate student at the University of Montana and was supported in part by funds from Associação para o Desenvolvimento da Aerodinâmica Industrial, the Blackfoot Forest Protective Association, and Fundação Luso-Americana para o Desenvolvimento.

\section{References}

Agee JK (1983) Fuel weights of understory-grown conifers in southern Oregon. Canadian Journal of Forest Research 13, 648-656.

Agee JK (1996) The influence of forest structure on fire behavior. In 'Proceedings of the 17 th annual forest vegetation management conference, Redding, CA, January 16-18, 1996'. pp. 52-68.

Agee JK, Bahro B, Finney MA, Omi PN, Sapsis DB, Skinner CN, van Wagtendonk JW, Weatherspoon CP (2000) The use of shaded fuelbreaks in landscape fire management. Forest Ecology and Management 127, 55-66.

Agee JK, Wright CS, Williamson N, Huff MH (2002) Foliar moisture content of Pacific Northwest vegetation and its relation to wildland fire behavior. Forest Ecology and Management 167, 57-66.

Albini, FA (1979) Spot fire distance from burning trees - a predictive model. USDA Forest Service, Intermountain Forest and Range Experiment Station General Technical Report INT-56. Ogden UT. 31 pp.

Albini FA (1996) Iterative solution of the radiation transport equations governing spread of fire in wildland fuel. Fizika Goreniya I Vzryva 32(5), 71-82.

Albini FA, Stocks BJ (1986) Predicted and observed rates of spread of crown fires in immature jack pine. Combustion Science and Technology 48, 65-76.

Alexander ME (1979) Fuels description in lodgepole pine stands of the Colorado Front Range. MSc thesis, Colorado State University. Fort Collins. $150 \mathrm{pp}$

Alexander ME (1988) Help with making crown fire hazard assessments. In 'Protecting people and homes from wildfire in the Interior
West'. (Compilers WC Fischer and SF Arno) USDA Forest Service, Intermountain Research Station General Technical Report INT-251. pp. 147-156. Ogden, UT.

Alexander ME (1998) Crown fire thresholds in exotic pine plantations of Australasia. PhD thesis, Australian National University, Canberra. $228 \mathrm{pp}$.

Alexander ME, Stocks BJ, Lawson BD (1991) Fire behavior in black spruce-lichen woodland: the Porter Lake project. Forestry Canada, Northern Forestry Centre, Edmonton, AB, Information Report NOR$\mathrm{X}-310.44 \mathrm{pp}$.

Amiro BD (1990) Comparison of turbulence statistics within three boreal forest canopies. Boundary-Layer Meteorology 51, 99-121.

Anderson HE (1974a) Forest fire retardant: transmission through a tree crown. USDA Forest Service, Intermountain Forest and Range Experiment Station Research Paper INT-153. Ogden, UT. 20 pp.

Anderson HE (1974b) Appraising forest fuels: a concept. USDA Forest Service, Intermountain Forest and Range Experiment Station Research Note INT-187. Ogden, UT. 10 pp.

Anderson HE (1983) Predicting wind driven wild land fire size and shape. USDA Forest Service, Intermountain Forest and Range Experiment Station Research Paper INT-305. Ogden, UT. 25 pp.

Andrews PL (1986) BEHAVE: Fire behavior prediction and fuel modeling system-BURN subsystem, part 1. USDA Forest Service, Intermountain Forest and Range Experiment Station General Technical Report INT-260. Ogden, UT. 130 pp.

Baldwin VC, Peterson KD, Burkhart HE, Amateis RL, Dougherty PM (1997) Equations for estimating loblolly pine branch and foliage weight and surface area distributions. Canadian Journal of Forest Research 27, 918-927.

Baskerville GL (1972) Use of logarithmic regression in the estimation of plant biomass. Canadian Journal of Forest Research 2, 49-53.

Baskerville GL (1983) Balsam fir foliage regressions are age dependent. Canadian Journal of Forest Research 13, 1248-1251.

Bilgili E, Methven IR (1994) A dynamic fuel model for use in managed even-aged stands. International Journal of Wildland Fire 4, $177-185$.

Brown JK (1978) Weight and density of crowns of Rocky Mountain conifers. USDA Forest Service, Intermountain Forest and Range Experiment Station Research Paper INT-197. Ogden UT. $56 \mathrm{pp}$.

Brown JK, Bevins CD (1986) Surface fuel loadings and predicted fire behavior for vegetation types in the Northern Rocky Mountains. USDA Forest Service, Intermountain Forest and Range Experiment Station Research Note INT-358. Ogden, UT. 9 pp.

Brown JK, See TE (1981) Downed dead woody fuel and biomass in the Northern Rocky Mountains. USDA Forest Service, Intermountain Forest and Range Experiment Station General Technical Report INT-117. Ogden, UT. 48 pp.

Burgan RE, Rothermel RC (1984) BEHAVE: Fire behavior prediction and fuel modeling system-FUEL subsystem. USDA Forest Service, Intermountain Forest and Range Experiment Station Research Paper INT-167. Ogden UT. 126 pp.

Byram GM (1959) Combustion of forest fuels. In 'Forest fire: Control and use'. (Ed. KP Davis) pp. 61-89, 554-555. (McGraw-Hill: New York)

Call PT, Albini FA (1997) Aerial and surface fuel consumption in crown fires. International Journal of Wildland Fire 7, 259-264.

Cole DM, Jensen CE (1982) Models for describing vertical crown development of lodgepole pine stands. USDA Forest Service, Intermountain Forest and Range Experiment Station Research Paper INT-292. Ogden, UT. 10 pp.

Cruz MG (1999) Modeling the initiation and spread of crown fires. MSc thesis, University of Montana, Missoula. $162 \mathrm{pp}$. 
Cruz MG, Viegas DX (1998) Crown fuel dynamics in bluegum eucalyptus (Eucalyptus globulus Labill.) plantations fuel complex: implications on extreme fire behavior phenomena. In 'Proceedings of 3rd International Conference on Forest Fire Research/14th Conference on Fire and Forest Meteorology, Luso-Coimbra, Portugal, 16-20 November 1998'. University of Coimbra, Coimbra, Portugal. pp. 2089-2109.

Draper NR, Smith H (1981) 'Applied regression analysis.' (John Wiley and Sons: New York) $407 \mathrm{pp}$.

Fiedler CE, Keegan CE, Woodall CW, Morgan TA, Robertson SH, Chmelik JT (2001) A strategic assessment of fire hazard in Montana. Report submitted to the Joint Fire Sciences Program, Boise, ID. 39 pp. [see http://www.nifc.gov/joint_fire_sci/deliverables.htm]

Finney MA (1998) FARSITE: Fire Area Simulator-model development and evaluation. USDA Forest Service, Rocky Mountain Research Station Research Paper RMRS-RP-4. Ogden, UT. 47 pp.

Forestry Canada Fire Danger Group (1992) Development and structure of the Canadian Forest Fire Behavior Prediction System. Forestry Canada, Science and Sustainable Development Directorate, Ottawa, ON. Information Report ST-X-3. 65 pp.

Fulé PZ, Waltz AEM, Covington WW, Heinlein TA (2001) Measuring forest restoration effectiveness in reducing hazardous fuels. Journal of Forestry 99(11), 24-29.

Gillespie AJR (1999) Rationale for a national annual forest inventory program. Journal of Forestry 97, 16-20.

Graham RT, Harvey AE, Jain TB, Tonn JR (1999) The effects of thinning and similar stand treatments on fire behavior in Western forests. USDA Forest Service, Pacific Northwest Research Station General Technical Report PNW-GTR-463. Portland, OR. 27 pp.

Green DC, Grigal DF (1978) Generalized biomass estimation equations for jack pine (Pinus banksiana Lamb.). Minnesota Forestry Research Notes No. 268. (University of Minnesota, College of Forestry: St. Paul) 4 pp.

Grigal DF, Kernik LK (1984) Generality of black spruce biomass estimation equations. Canadian Journal of Forest Research 14, $468-470$.

Grishin AM (1997) 'Mathematical modeling of forest fires and new methods of fighting them.' (Tomsk State University: Tomsk, Russia) $390 \mathrm{pp}$.

Johnson KN, Sessions J, Franklin J, Gabriel J (1998) Integrating wildfire into strategic planning for Sierra Nevada forests. Journal of Forestry 96(1), 42-49.

Johnson AF, Woodard PM, Titus SJ (1990) Lodgepole pine and white spruce crown fuel weights predicted from diameter at breast height. The Forestry Chronicle 66, 596-599.

Keane RE, Garner JL, Schmidt KM, Long DG, Menakis JP, Finney MA (1998) Development of input data layers for the FARSITE fire growth model for the Selway-Bitterroot Wilderness complex, USA. USDA Forest Service, Rocky Mountain Research Station General Technical Report RMRS-GTR-3. Ogden, UT. 66 pp.

Keyes CR, O'Hara KL (2002) Quantifying stand targets for silvicultural prevention of crown fires. Western Journal of Applied Forestry 17, $101-109$

Kiil AD (1967) Fuel weight tables for white spruce and lodgepole pine crowns in Alberta. Canada Department of Forestry and Rural Development, Forestry Branch, Ottawa, ON. Departmental Publication No. $1196.13 \mathrm{pp}$.

Kilgore BM (1981) Fire in ecosystem distribution and structure: western forests and scrublands. In 'Proceeding of the conference fire regimes and ecosystem properties'. USDA Forest Service, General Technical Report WO-26. Washington, D.C. pp. 58-89.

Kilgore BM, Sando RW (1975) Crown-fire potential in a sequoia forest after prescribed burning. Forest Science 2, 83-87.

Kittredge J (1944) Estimation of the amount of foliage of trees and stands. Journal of Forestry 42, 905-912.
Kozak A (1997) Effects of multicollinearity and autocorrelation on the variable-exponent taper functions. Canadian Journal of Forest Research 27, 619-629.

Lawson BD (1972) Fire spread in lodgepole stands. MSc thesis, University of Montana, Missoula. 119 pp.

Long JN, Smith FW (1988) Leaf area-sapwood area relations of lodgepole pine as influenced by stand density and site index. Canadian Journal of Forest Research 18, 247-250.

Loomis RM, Roussopoulos PJ (1978) Estimating aspen crown fuels in northern Minnesota. USDA Forest Service, North Central Forest Experiment Station Research Paper NC-156. St. Paul, MN. 6 pp.

McAlpine RS, Hobbs MW (1994) Predicting the height to live crown base in plantations of four boreal forest species. International Journal of Wildland Fire 4, 103-106.

Mead BR (1998) Phytomass in Southeast Alaska. USDA Forest Service, Pacific Northwest Research Station Research Paper PNW-RP-505. Portland, OR. 48 pp.

Mercer GN, Weber RO (1994) Plumes above line fires in a cross wind. International Journal of Wildland Fire 4, 201-207.

Meyers TP, Paw U KT (1987) Modeling the plant canopy micrometeorology with higher-order closure principles. Agriculture and Forest Meteorology 41, 143-163.

Moeur M (1981) Crown width and foliage weight of Northern Rocky Mountain conifers. USDA Forest Service, Intermountain Forest and Range Experiment Station Research Paper INT-283. Ogden, UT. $14 \mathrm{pp}$.

Monserud RA, Marshal JD (1999) Allometric crown relations in three northern Idaho conifer species. Canadian Journal of Forest Research 29, 521-535.

Muraro SJ (1971) The lodgepole pine fuel complex. Canadian Forestry Service, Forest Research Laboratory, Victoria, BC. Information Report BC-X-53. 50 pp.

NFPA (1990) Black Tiger Fire case study. National Fire Protection Association, Quincy, MA. 40 pp. [republished as by National Wildfire Coordinating Group, Boise, ID, as National Fire Equipment System Publication NFES 2130.]

Norušis MJ (1997) SPSS professional statistics. (SPSS Inc.: Chicago) $376 \mathrm{pp}$.

Ottmar RD, Vihnanek RE, Wright CS (1998) Stereo photo series for quantifying natural fuels. Volume I: Mixed-conifer with mortality, western juniper, sagebrush, and grassland types in the Interior Pacific Northwest. National Fire Equipment System Publication NFES 2580. (National Wildfire Coordinating Group: Boise, ID) 73 pp.

Rencz AN, Auclair AN (1980) Dimension analysis of various components of black spruce in subarctic lichen woodlands. Canadian Journal of Forest Research 10, 491-497.

Rothermel RC (1991) Predicting behavior and size of crown fires in Northern Rocky Mountains. USDA Forest Service, Intermountain Research Station Research Paper INT-438. Ogden, UT. 46 pp.

Rothermel RC, Wilson RA Jr, Morris GA, Sackett SS (1986) Modeling moisture content of fine dead fuels: input to the BEHAVE fire prediction system. USDA Forest Service, Intermountain Research Station Research Paper INT-359. Ogden, UT. 61 pp.

Sando RW, Wick CH (1972) A method for evaluating crown fuels in forest stands. USDA Forest Service, North Central Forest Experiment Station Research Paper NC-84. St. Paul, MN. 26 pp.

Scott JH (1998) Fuel reduction in residential and scenic forests: A comparison of three treatments in a western Montana ponderosa pine stand. USDA Forest Service, Rocky Mountain Research Station Research Paper RMRS-RP-5. Ogden, UT. 19 pp.

Scott JH, Reinhardt ED (2001) Assessing crown fire potential by linking models of surface and crown fire. USDA Forest Service, Rocky Mountain Research Station Research Paper RMRS-RP-29. Fort Collins, CO. 59 pp. 
Snell JAK, Anholt BF (1981) Predicting crown weight of coast Douglasfir and western hemlock. USDA Forest Service, Pacific Northwest Forest and Range Experiment Station Research Paper PNW-281. Portland, OR. 12 pp.

Stephens SL (1998) Evaluation of the effects of silvicultural and fuels treatment on potential fire behavior in Sierra Nevada mixed conifer forests. Forest Ecology and Management 105, 21-35.

Stiell WM (1969) Crown development in white spruce plantations. Forestry Branch, Canada Department of Fisheries and Forestry, Forestry Branch, Ottawa, ON. Canada, Departmental No. 1249. $11 \mathrm{pp}$.

Stocks BJ (1980) Black spruce crown fuel weights in northern Ontario. Canadian Journal of Forest Research 10, 498-501.

Stocks BJ (1987) Fire behavior in immature jack pine. Canadian Journal of Forest Research 17, 80-86.

Stocks BJ (1989) Fire behavior in mature jack pine. Canadian Journal of Forest Research 19, 783-790.

Ter-Mikaelian MT, Korzukhin MD (1997) Biomass equations for sixtyfive North American tree species. Forest Ecology and Management 97, 1-24.

Van Wagner CE (1968) Fire behaviour mechanisms in a red pine plantation: field and laboratory evidence. Canada Department of Forestry and Rural Development, Forestry Branch, Ottawa, ON. Departmental Publication No. 1229. 30 pp.
Van Wagner CE (1977) Conditions for the start and spread of crown fire. Canadian Journal of Forest Research 7, 23-34.

Van Wagner CE (1989) Prediction of crown fire behavior in conifer stands. In 'Proceedings of 10th conference on fire and forest meteorology'. (Eds DC MacIver, H Auld and R Whitewood) pp. 207-212. (Forestry Canada and Environment Canada: Ottawa, ON)

Weber RO, Gill AM, Lyons PRA, Moore PHR, Bradstock RA, Mercer GN (1995) Modelling wildland fire temperatures. CALMScience Supplement 4, 23-26.

Weetman GF, Harland R (1964) Foliage and wood production in unthinned black spruce in northern Quebec. Forest Science 10, $80-88$.

Wendel GW (1960) Fuel weights of pond pine crowns. USDA Forest Service, Southeastern Forest Experiment Station Research Note No. 149. Asheville, NC. 2 pp.

Woudenberg SW, Farrenkopf TO (1995) The Westwide forest inventory data base: User's manual. USDA Forest Service, Intermountain Research Station General Technical Report INT-317. Ogden, UT. $67 \mathrm{pp}$.

Xanthopoulos G (1990) Development of a wildland crown fire initiation model. PhD thesis, University of Montana, Missoula. $152 \mathrm{pp}$. 